\title{
A synoptic climatology of heavy rain events in the Lake Eyre and Lake Frome catchments
}

\author{
Michael J. Pook ${ }^{1 *}$, James S. Risbey ${ }^{1}$, Caroline C. Ummenhofer ${ }^{2}$, Peter R. Briggs $^{3}$ and \\ Timothy J. Cohen 4 \\ ${ }^{1}$ Commonwealth Scientific and Industrial Research Organisation Oceans and Atmosphere, Hobart, TAS, Australia \\ 2 Department of Physical Oceanography, Woods Hole Oceanographic Institution, Woods Hole, MA, USA \\ ${ }^{3}$ Commonwealth Scientific and Industrial Research Organisation Oceans and Atmosphere, Canberra, ACT, Australia \\ ${ }^{4}$ GeoQuest Research Centre, School of Earth and Environmental Sciences, University of Wollongong, Wollongong, NSW, Australia
}

\section{Edited by:}

Emanuel Dutra, European Centre for Medium-Range Weather Forecasts, UK

\section{Reviewed by:}

Olivia Martius, University of Bern, Switzerland

Eduardo Zorita, Hemlholtz-Zentrum Geesthacht, Germany

\section{*Correspondence:}

Michael J. Pook, Commonwealth

Scientific and Industrial Research Organisation Oceans and

Atmosphere Flagship, GPO Box

1538, Hobart, TAS 7001, Australia

e-mail:mike.pook@csiro.au
The rare occasions when Lake Eyre in central, southern Australia fills with water excite great interest and produce major ecological responses. The filling of other smaller lakes such as Lake Frome have less impact but can contribute important information about the current and past climates of these arid regions. Here, the dominant synoptic systems responsible for heavy rainfall over the catchments of Lake Eyre and Lake Frome since 1950 are identified and compared. Heavy rain events are defined as those where the mean catchment rainfall for $24 \mathrm{~h}$ reaches a prescribed threshold. There were 25 such daily events at Lake Eyre and 28 in the Lake Frome catchment. The combination of a monsoon trough at mean sea level and a geopotential trough in the mid-troposphere was found to be the synoptic system responsible for the majority of the heavy rain events affecting Lake Eyre and one in five of the events at Lake Frome. Complex fronts where subtropical interactions occurred with Southern Ocean fronts also contributed over $20 \%$ of the heavy rainfall events in the Frome catchment. Surface troughs without upper air support were found to be associated with $10 \%$ or fewer of events in each catchment, indicating that mean sea level pressure analyses alone do not adequately capture the complexity of the heavy rainfall events. At least $80 \%$ of the heavy rain events across both catchments occurred when the Southern Oscillation Index (SOI) was in its positive phase, and for Lake Frome, the SOI exceeded +10 on $60 \%$ of occasions, suggesting that the background atmospheric state in the Pacific Ocean was tilted toward La Niña. Hydrological modeling of the catchments suggests that the 12-month running mean of the soil moisture in a sub-surface layer provides a low frequency filter of the precipitation and matches measured lake levels relatively well.

\section{Keywords: synoptic, front, monsoon trough, upper trough, cutoff low, Australia, Lake Eyre}

\section{INTRODUCTION}

The lakes of Australia's arid interior are ephemerally filled and are for most of the time salt-crusted playa surfaces. The filling of such large playa lakes (including Australia's largest-Lake Eyre) is therefore an important climatological phenomenon triggering large-scale ecological responses (e.g., Kingsford and Porter, 1995; Poulter et al., 2014) and also being of great socio-economic and general cultural interest. Indeed, the "inland sea" of Australia was what many early explorers were searching for Cathcart (2009). The reality however is that such filling events occur rarely and under specific conditions only. Many of Australia's playa lakes lack significant catchment areas (relative to lake area) and are predominantly groundwater-fed, making them highly susceptible to evaporative processes. Others have large contributing catchment areas in the arid-zone (e.g., Lake Torrens or Lake Frome) or from the tropical northern latitudes (e.g., Lake Eyre). Most have contributing rivers which experience high transmission losses of discharge en route to the terminal lakes (Knighton and Nanson, 1994).
A number of attempts have been made to document the historical filling of Lake Eyre but little other work exists which documents when and how other large playa lakes (e.g., Torrens or Frome) have filled. Earlier work by the Lake Eyre Committee (1955) and Bonython and Fraser (1989) provide a useful review to some of the earlier lake fillings of Australia's largest lake, whilst Kotwicki (1986) provides a comprehensive assessment of the Lake Eyre Basin hydrological characteristics. Subsequent work by Kotwicki and Isdale (1991) has attempted to correlate historical Lake Eyre filling to proxy climate records and large-scale climatic influences, of which the El Niño-Southern Oscillation (ENSO) phenomenon is the dominant driver. The larger arid-zone lake systems also record a long history of fluctuating climate with the work of Magee et al. (2004) and Cohen et al. (2011, 2012a) all demonstrating that these inland catchments were much wetter about $100,000-50,000$ years ago than at present with the presence of large "megalakes" and associated Pleistocene megafauna (Webb, 2010). Even more recently in the geological past (e.g., the medieval climatic anomaly, $\sim 1000$ years ago) it has been shown 
that the Lake Frome-Callabonna system experienced exceptionally wet events that produced aggradational evidence of past lake filling (Cohen et al., 2012b; Gliganic et al., 2014).

It is not known what synoptic and climatic conditions were responsible for ancient lake fillings. However, there are reliable synoptic data available for the period since about 1950 and analysis of this data set provides the opportunity to examine the modern circulation types associated with large rainfall events in these arid zone catchments. The results of this analysis may then offer some insights into the characteristics of the enhanced rainfall periods in the geological record. Hence, in this paper we investigate the types of synoptic systems responsible for a selection of recent historical heavy rainfall events over the catchments of Lake Eyre and Lake Frome using accepted methods of synoptic climatology (e.g., Pook et al., 2006, 2012, 2014). We compare and contrast the dominant systems affecting the Lake Eyre catchment with those contributing to major events in the Lake Frome catchment. Both lakes are located in southern central Australia (Figure 1) and the lakes themselves fall within relatively uniform rainfall distribution zones. However, the headwaters of Lake Eyre lie within the summer-dominated rainfall zone of the tropical north and the headwaters of the Frome-Callabonna system are largely confined within the winter-dominated rainfall zone.

Lake-filling occurrences are not the result of isolated heavy precipitation events in the arid interior of Australia but rather follow extended periods of widespread rainfall over the catchments. While it is important to categorize the synoptic systems responsible for individual heavy rain events, it is also essential to place these synoptic events within the background atmospheric state. The intensity of the Australian monsoon has been shown to have a strong association with the filling of Lake Eyre (Allan, 1985) and historical evidence indicates that most episodes of enhanced

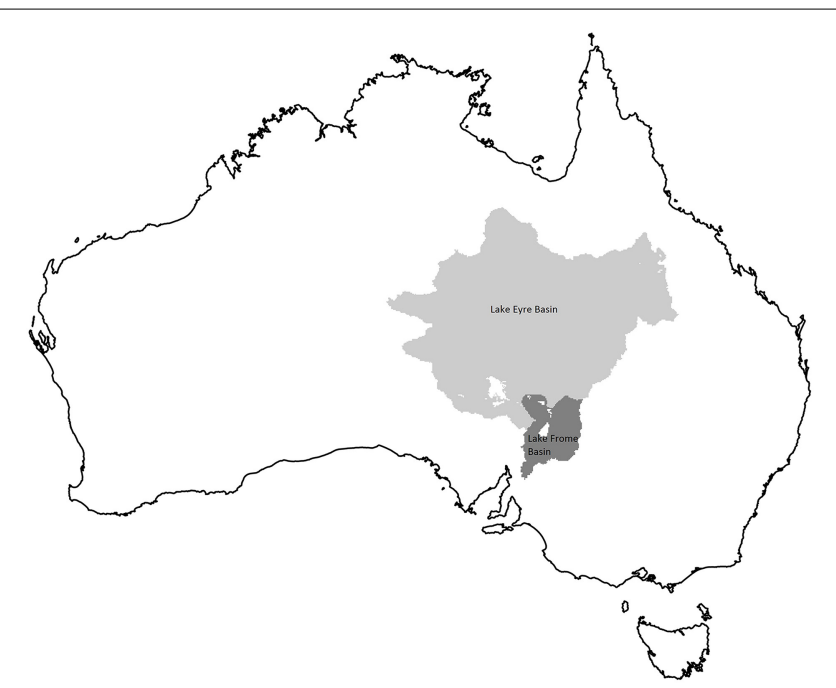

FIGURE 1 | Location of the Eyre (mid-gray) and Frome (dark-gray) drainage basins at $0.05 \times \mathbf{0 . 0 5 ^ { \circ }}$ resolution. White areas within the basins are included in the analysis of the Australian Bureau of Meteorology daily rainfall (Jones et al., 2009) but excluded from the CSIRO Australian Water Availability Project monthly model outputs due to missing soil information (Raupach et al., 2009). precipitation in subtropical and tropical Australia occur during the La Niña phase of ENSO (e.g., Allan et al., 1996, and references therein). Risbey et al. (2009) have shown that, among the various indices of ENSO in current use, the Southern Oscillation Index (SOI) has the highest simultaneous correlation with Australian rainfall. The correlation is positive. Sustained positive values of the SOI above a specified threshold tend to be associated with La Niña. Consequently, the mean monthly value of the SOI has been recorded for each of the heavy rain events examined in the synoptic analysis.

\section{DATA AND METHOD \\ DATA}

Daily rainfall data for each catchment for the period January 1, 1900 to February 28, 2014 were obtained by spatial averaging of the Australian Bureau of Meteorology's high-quality gridded rainfall surfaces at $0.05 \times 0.05^{\circ}$ resolution, prepared for the Australian Water Availability Project (AWAP) (Jones et al., 2009; Australian Bureau of Meteorology, 2014). Areas of missing daily data due to sparse network interpolation failure were filled with disaggregated monthly data interpolated using a larger length scale. Commonwealth Scientific and Industrial Research Organisation (CSIRO) AWAP model outputs of water fluxes and soil moisture in a near-surface (approximately 0 to $0.2 \mathrm{~m}$ ) and a sub-surface layer (approximately 0.2 to $2 \mathrm{~m}$ ) at monthly resolution (Raupach et al., 2009, 2014) were generated using the AWAP WaterDyn model (version $26 \mathrm{M}$ ) driven by the same daily rainfall data and corresponding daily temperature and solar radiation data. The relative soil moisture in the AWAP product is defined as a fraction of the saturated water-holding capacity of the soil and is dimensionless. Spatial averages of AWAP model outputs exclude areas not modeled due to missing soil parameter information, shown as white areas within the two catchments (see Figure 1). These areas are unrelated to the areas filled with monthly rainfall data, but may overlap them.

The synoptic analysis was primarily based on the National Centers for Environmental Prediction (NCEP) - National Center for Atmospheric Research (NCAR) climate reanalysis data set (Reanalysis 1) (Kalnay et al., 1996; Kistler et al., 2001). The NCEP data consist of 4 analyses per day (at 6-hourly intervals from 0000 UTC) at a resolution of $2.5^{\circ}$ latitude by $2.5^{\circ}$ longitude for the standard atmospheric levels from the surface to the lower stratosphere. The reanalysis data are available from January 1948 although the Australian data have been used with caution prior to 1956 as the upper air data network was quite sparse prior to that time (Pook et al., 2012). The key fields sampled in the analysis were mean sea level pressure (MSLP), the $500 \mathrm{hPa}$ geopotential height, the (computed) 1000-500 hPa atmospheric thickness and the $250 \mathrm{hPa}$ wind. Additionally, the 1000-500 hPa thickness anomaly relative to the long-term climatology for a particular month was calculated and displayed for each analysis.

The Reanalysis data set was supplemented by daily weather maps at 0000 UTC published in the Australian Bureau of Meteorology's "Monthly Weather Review" series (Simmonds and Richter, 2000). These charts include frontal analysis which has been performed manually by expert analysts employing interpretation of satellite imagery in addition to standard analysis of 
synoptic data (Guymer, 1978) and evaluation of output from a suite of numerical weather prediction models. Crucially, these charts provide the most reliable method of determining the occurrence of cold fronts, important rain-producing systems in southern Australia.

Monthly means of the SOI were obtained from the Australian Bureau of Meteorology (http://www.bom.gov.au/ climate/current/soihtm1.shtml) in order to determine the phase of the ENSO at the time of each of the heavy rain events. The calculation of the SOI has evolved over time (Allan et al., 1996). In this paper the SOI is expressed as the monthly mean of the normalized pressure difference between Tahiti and Darwin.

\section{METHOD}

For each day on which the mean rainfall across the particular catchment network was greater than or equal to a threshold value, a particular synoptic system was identified as being responsible for the precipitation event. For the vast Lake Eyre catchment (see Figure 1), a threshold of $20 \mathrm{~mm}$ per day was selected for the heavy rainfall events in order to include isolated events large enough to produce runoff and therefore have the potential to contribute to lake filling episodes. For the much smaller Lake Frome catchment the threshold for the daily mean catchment rainfall of a heavy rainfall event was set at $25 \mathrm{~mm}$ per day. This approach produced comparable numbers of events in each catchment.

The primary classification of synoptic systems followed Pook et al. (2006, 2012, 2014) who specified three main categories: cold frontal systems associated with Southern Ocean depressions; cold-cored lows that have become separated from the westerly flow (cutoff lows); and a broad category labeled "other synoptic systems" that included, inter alia, troughs in the surface easterlies (easterly troughs) and cold troughs in the middle troposphere where a closed circulation was not present at $500 \mathrm{hPa}$. In this study the upper trough was required to contain a region of negative anomaly of 1000-500 hPa thickness of at least 20 geopotential meters. Within the cold frontal category, Pook et al. (2006) identified three main types of front; simple, complex and waves. The complex front is identified by the presence of a well-defined prefrontal trough which extends southwards from the subtropics and may interact with an existing subtropical cloud band. Expert judgment from forecasting and analysis experience was applied in order to make a realistic estimate of the typical displacement of synoptic systems in order to ensure that the system was located over the catchment during the $24 \mathrm{~h}$ period in which the rainfall was recorded.

As this analysis extends over the austral summer, an extra category of "monsoon trough" has been added. The monsoon trough was identified by the analyst in cases where the shear line between the low-level westerlies in the north and the southeast trades in the south as inferred from the isobaric pattern was located over northern Australia (McBride, 1998), and in close proximity to or over the Lake Eyre Basin (see Figure 1). The Australian monsoon is intermittent in intensity and southward extent (Sturman and Tapper, 1996) tends to develop well into the austral summer and is characterized by periods of days or weeks of relative inactivity known as "breaks." However, semi-permanent heat lows remain anchored over northwestern Australia and northeastern Australia throughout the summer half of the year (Sturman and Tapper, 1996) but are rarely associated with widespread rain.

For each event, the MSLP, $500 \mathrm{hPa}$, and the $1000-500 \mathrm{hPa}$ thickness analyses were carefully evaluated. Hence, synoptic types have been specified according to a combination of MSLP and upper air criteria. As an example, Figure 2 shows typical MSLP and $500 \mathrm{hPa}$ analyses for the synoptic classification referred to as "monsoon trough/upper trough."

\section{RESULTS}

\section{LAKE EYRE CATCHMENT}

Over the period from January 1950 to February 2014 there were 25 individual events for which the mean daily rainfall for the Lake Eyre catchment (see Figure 1) was $20 \mathrm{~mm}$ or more. However, there were consecutive days of heavy rainfall in a number of these cases and this consideration reduces the number of independent episodes of heavy rain over the catchment to 15 in that 64 -year period. Table 1 records the results of the synoptic analysis of the heavy rain events in the Lake Eyre catchment.

The dominant system found to be responsible for the heavy rain events was the combination of a monsoon trough of low pressure on the MSLP surface and an upper trough as determined by the $500 \mathrm{hPa}$ geopotential and $1000-500 \mathrm{hPa}$ thickness analyses. An example of this synoptic type is shown in Figure 2. There were 15 events of this type.

Troughs in the easterlies which were not assessed as satisfying the requirements of the monsoon trough but were associated with an upper trough on the $500 \mathrm{hPa}$ surface were analyzed as the

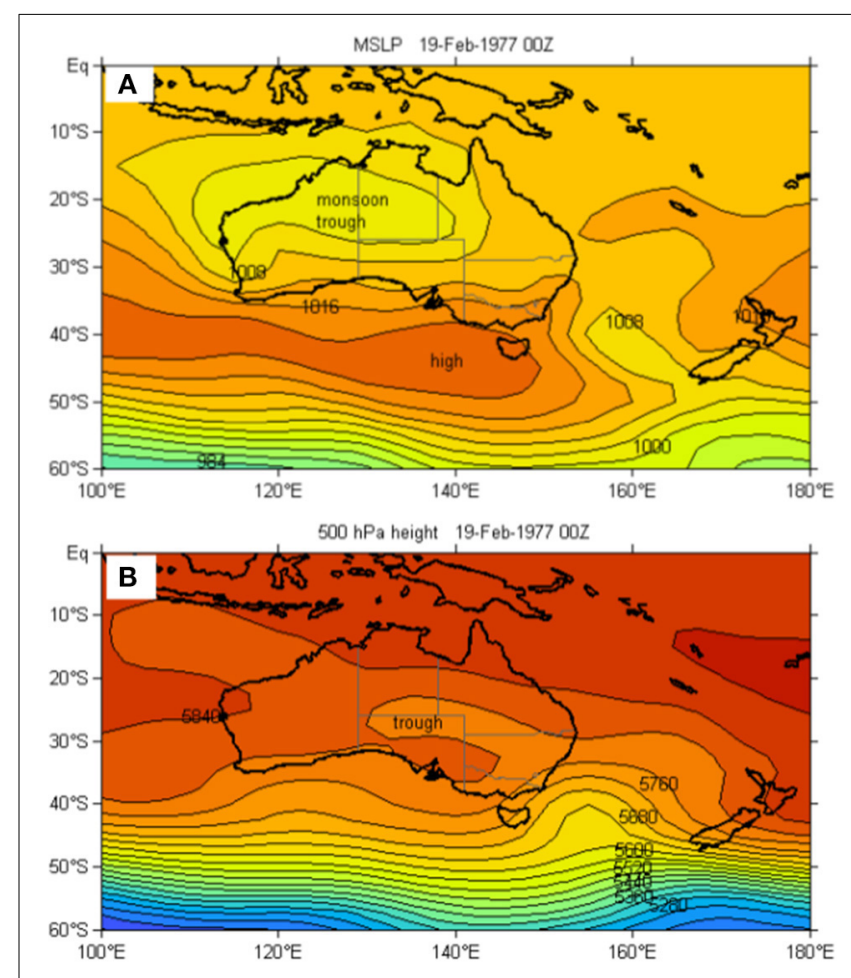

FIGURE 2 | The synoptic type classified as a monsoon trough at MSLP (A) combined with an upper atmospheric trough at $500 \mathrm{hPa}(\mathrm{B})$ 
Table 1 | Heavy daily rainfall events in the Lake Eyre catchment and the accompanying synoptic type as determined by the synoptic analysis.

\begin{tabular}{|c|c|c|}
\hline Date & $\begin{array}{l}\text { Mean catchment rain } \\
\text { (mm/day) }\end{array}$ & Synoptic analysis \\
\hline 24-May-1955 & 23 & E/ly Tr/upper Tr \\
\hline 25-May-1955 & 23 & E/ly Tr/upper Tr \\
\hline 29-April-1968 & 21 & cutoff low \\
\hline 05-March-1972 & 22 & monsoon Tr/upper $\mathrm{Tr}$ \\
\hline 06-March-1972 & 21 & monsoon Tr/upper $\mathrm{Tr}$ \\
\hline 07-February-1976 & 22 & monsoon Tr/upper $\mathrm{Tr}$ \\
\hline 08-February-1976 & 24 & monsoon Tr/upper $\mathrm{Tr}$ \\
\hline 09-February-1976 & 24 & monsoon $\mathrm{Tr} / \mathrm{upper} \mathrm{Tr}$ \\
\hline 18-February-1977 & 21 & monsoon Tr/upper $\mathrm{Tr}$ \\
\hline 19-February-1977 & 26 & monsoon Tr/upper $\mathrm{Tr}$ \\
\hline 20-February-1977 & 23 & monsoon $\mathrm{Tr} / \mathrm{upper} \mathrm{Tr}$ \\
\hline 10-July-1978 & 21 & E'ly Tr/upper Tr \\
\hline 21-May-1981 & 21 & E'ly Tr/upper Tr \\
\hline 12-January-1984 & 24 & monsoon Tr/cutoff low \\
\hline 13-January-1984 & 30 & monsoon Tr/cutoff low \\
\hline 31-March-1988 & 25 & E'ly Tr/upper Tr \\
\hline 21-May-1990 & 22 & E'ly Tr/cutoff low \\
\hline 22-May-1990 & 24 & cutoff low \\
\hline 06-February-1991 & 22 & monsoon $\mathrm{Tr}$ \\
\hline 28-February-1992 & 21 & monsoon Tr/upper $\mathrm{Tr}$ \\
\hline 18-January-1995 & 29 & monsoon Tr/upper $\mathrm{Tr}$ \\
\hline 19-January-1995 & 26 & cutoff low \\
\hline 21-January-2007 & 22 & monsoon $\operatorname{Tr} /$ upper $\operatorname{Tr}$ \\
\hline 28-February-2010 & 25 & monsoon $\mathrm{Tr} / \mathrm{upper} \mathrm{Tr}$ \\
\hline 01-March-2010 & 26 & monsoon Tr/upper $\mathrm{Tr}$ \\
\hline
\end{tabular}

The abbreviation "Tr" has been used for "trough."

progenitors of a further 5 heavy rainfall events. One surface easterly trough was accompanied by a cutoff low at $500 \mathrm{hPa}$ and 3 heavy rain events were associated with cutoff lows identifiable in both the upper air and at MSLP. Two of these events occurred in the austral autumn. Only one event was found to be caused by a surface trough without an accompanying trough in the middle and upper atmosphere. Additionally, only one heavy rain event occurred in the austral winter (10 July, 1978) and none in the austral spring, thus confirming the strong bias toward major rain events in the Lake Eyre catchment during summer and autumn.

For one event (21 January, 2007), an active monsoon trough was located over northern Australia while a cutoff low was centered just to the southwest of Adelaide and extended a cold trough at $500 \mathrm{hPa}$ northwards over the Lake Eyre Basin. Although this location of the cutoff low would normally not be associated of itself with heavy rainfall over the majority of the Lake Eyre catchment, Figure 3A indicates that the warm conveyor belt on the eastern side of the cutoff system at 1200 UTC on (20 January, 2007) channeled moisture further southwards than would otherwise have occurred. The enhanced vertical motion leading to heavy rain is displayed in Figure 3B for the track indicated with the arrow in Figure 3A. This back trajectory shows air of high specific humidity originating in the boundary layer over the ocean to

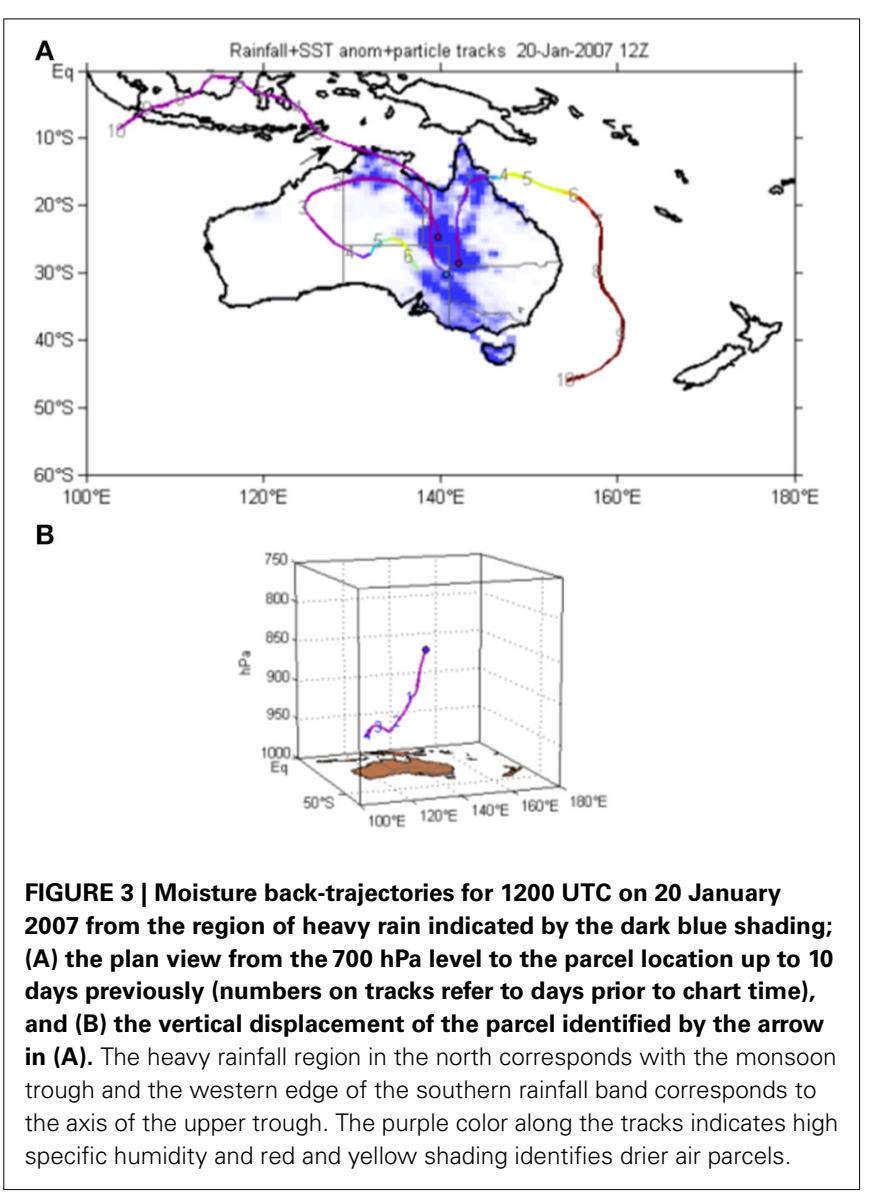

the northwest of Australia and passing over northern Australia 2 days prior to chart time and rapidly ascending as it moved southwards. In this example, the axis of the monsoon trough at MSLP is closely aligned with the heavy rainfall region depicted in the north by the dark blue shading. The axis of the upper trough lies near the western edge of the southern rain band.

\section{LAKE FROME CATCHMENT}

For the analysis period, there were 28 heavy rainfall events resulting in an average daily rainfall of $25 \mathrm{~mm}$ or more over the Lake Frome catchment (Table 2). On four occasions, two or more days of heavy rain occurred consecutively. Clearly, the higher latitude of Lake Frome largely excludes its catchment from the meteorological activity so typical of the tropics in the monsoon season. Nevertheless, there were 5 days in the analysis when heavy rainfall events were recorded in both catchments concurrently. These 5 days were confined to three separate occurrences of heavy rain, in May 1955, February 1976 and January 1984. The mean catchment rainfall and the synoptic classification for the heavy rainfall events identified in the Lake Frome catchment are recorded in Table 2.

Monsoon troughs at MSLP combined with an upper trough were found to be responsible for about $20 \%$ of the 28 heavy rain events in the Lake Frome catchment. However, complex fronts were equally dominant causes of heavy rainfall events. These systems were characterized by strong interaction with a prefrontal trough and tropical moisture and often, a pre-existing subtropical 
Table 2 | Heavy daily rainfall events in the Lake Frome catchment and the accompanying synoptic type as determined by the analysis.

\begin{tabular}{|c|c|c|}
\hline Date & $\begin{array}{c}\text { Mean catchment rain } \\
\text { (mm/day) }\end{array}$ & Synoptic analysis \\
\hline 02-February-1950 & 25 & E'ly $\operatorname{Tr}$ \\
\hline 17-March-1950 & 47 & E'ly Tr/upper Tr \\
\hline 24-May-1955 & 27 & E'ly Tr/cutoff low \\
\hline 25-May-1955 & 36 & cutoff low \\
\hline 17-January-1962 & 30 & complex front \\
\hline 16-January-1968 & 25 & cutoff low \\
\hline 29-December-1973 & 31 & monsoon $\mathrm{Tr}$ \\
\hline 30-December-1973 & 26 & complex front \\
\hline 29-January-1974 & 30 & monsoon $\operatorname{Tr} /$ upper $\mathrm{Tr}$ \\
\hline 19-February-1974 & 27 & E'ly Tr/upper $\operatorname{Tr}$ \\
\hline 23-October-1975 & 25 & cutoff low \\
\hline 13-December-1975 & 32 & E'ly Tr/upper $\operatorname{Tr}$ \\
\hline 08-February-1976 & 30 & monsoon $\mathrm{Tr} /$ upper $\mathrm{Tr}$ \\
\hline 09-February-1976 & 49 & monsoon $\mathrm{Tr} /$ upper $\mathrm{Tr}$ \\
\hline 10-February-1976 & 26 & monsoon $\mathrm{Tr} /$ upper $\mathrm{Tr}$ \\
\hline 17-January-1979 & 25 & monsoon $\mathrm{Tr} / \mathrm{upper} \mathrm{Tr}$ \\
\hline 22-February-1979 & 26 & E'ly Tr/cutoff low \\
\hline 14-January-1984 & 44 & monsoon Tr/cutoff low \\
\hline 26-January-1984 & 30 & complex front \\
\hline 14-March-1989 & 49 & monsoonTr/upper $\mathrm{Tr}$ \\
\hline 10-January-1990 & 26 & E'ly Tr/cutoff low \\
\hline 16-March-1996 & 27 & complex front \\
\hline 07-February-1997 & 31 & E'ly $\operatorname{Tr}$ \\
\hline 12-February-2000 & 25 & complex front \\
\hline 06-February-2011 & 40 & complex front \\
\hline 29-February-2012 & 36 & E'ly Tr/upper Tr \\
\hline 1-March-2012 & 29 & E'ly Tr/upper Tr \\
\hline 15-February-2014 & 26 & E'ly $\operatorname{Tr}$ \\
\hline
\end{tabular}

The abbreviation "Tr" has been used for "trough."

cloud band, and are similar to the "interacting frontal types" of Wright $(1989,1997)$. All of these complex front cases occurred in the austral summer and autumn when tropical moisture would be most likely to be available.

The next most important category of synoptic systems is a trough in the easterly flow at MSLP accompanied by an upper trough. There were also three cases where cutoff lows were the dominant synoptic system associated with daily rain events and four events where cutoff lows were associated with a trough on the MSLP surface. Additionally, four events were associated with troughs at the surface that were not also accompanied by troughs in the middle and upper atmosphere.

\section{CATCHMENT COMPARISON}

Figure 4 shows the comparison between the percentage contributions of synoptic systems to heavy daily rainfall events in the Lake Eyre and Lake Frome catchments. At Lake Eyre, more than 80\% of cases involved an upper trough (including cutoff lows) associated with a trough at MSLP. Upper atmospheric systems were also important contributors to rainfall in the Lake Frome catchment where, in combination, they accounted for approximately $50 \%$

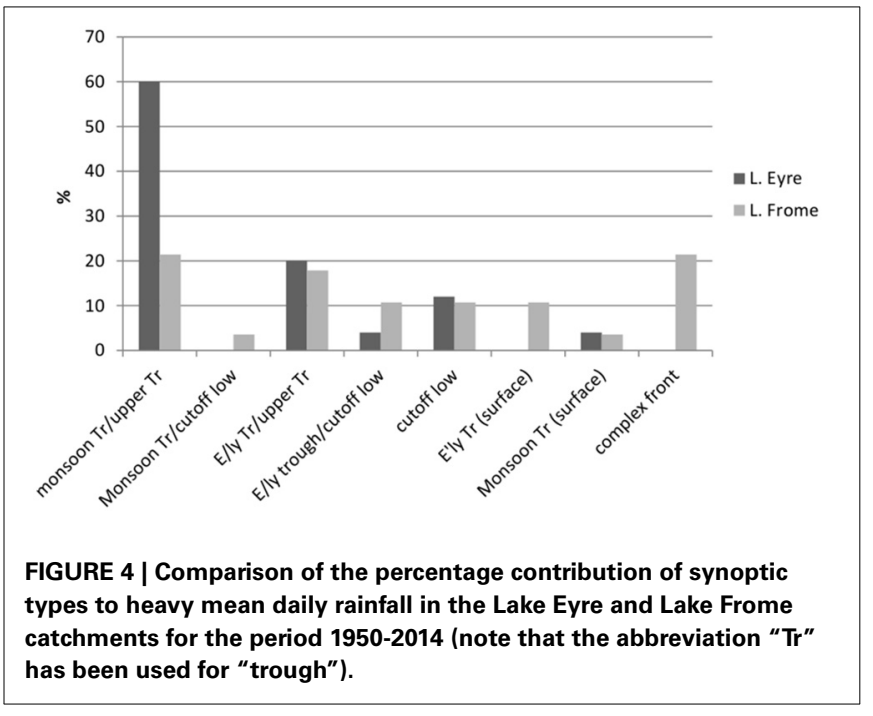

of events. Complex frontal systems were an equally important source of the Lake Frome heavy rain events (21\%) to monsoon troughs accompanied by an upper trough. In these cases interactions occurred between a frontal system associated with a Southern Ocean depression and a prefrontal trough over subtropical Australia. In each catchment, individual cutoff lows extending from the mid-troposphere into the lower atmosphere resulted in approximately $12 \%$ of heavy rain days.

\section{LAKE FILLING AND PRECIPITATION}

Water levels in Lake Eyre have been recorded or estimated over many decades by the Lake Eyre Yacht Club (Bye et al., 1978). Prior to 1979 , the lake levels were measured manually at Level Post Bay. Since 1979, satellite imagery in a range of visible and near-infrared wavelengths has become available for the Australian region from the LANDSAT series of polar-orbiting satellites. Interpretation of these data has been used to compile semi-quantitative lake levels with the addition of surface observations from 1973 to 1979 . The site chosen here for comparing lake levels to catchment precipitation is known as Belt Bay which is located in the southern end of Lake Eyre North.

In order to better match the relatively slow lake-filling events with hydrological data, monthly precipitation data from AWAP are presented in Figure 5A for the Lake Eyre catchment. These data have been used as input for the AWAP hydrological model which provides estimates of runoff, water drainage and soil moisture in the catchment. Additionally, Figure 5 shows upper soil moisture as a fraction of the total (B), lower soil moisture as a fraction of the total (C), and the estimated water level in Lake Eyre (D). The synoptic systems identified in the synoptic analysis as the dominant contributors to the individual heavy rain days are marked by colored triangles in Figures 5A,C. Prior to 1950, a synoptic type has not been assigned to each heavy rain event owing to the unavailability of reanalysis data.

In Figure 5, there is considerable noise in the monthly mean precipitation (A) and monthly mean of the upper soil moisture (B) (gray shading). The green line in each of the upper panels represents the 12-month running mean and provides a low 


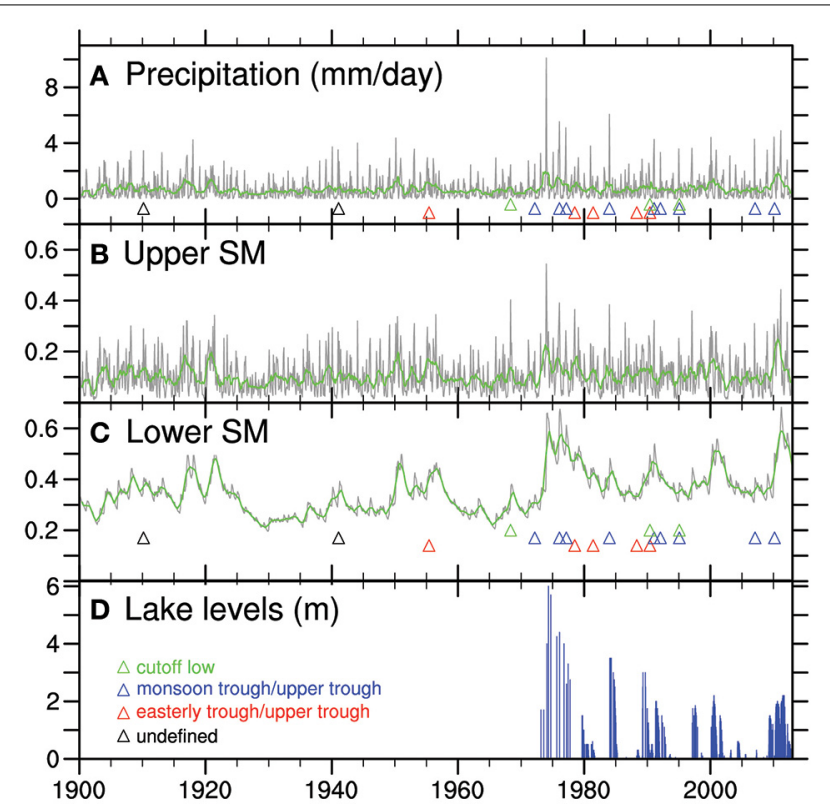

FIGURE 5 | Monthly means (gray shading) and 12-month running means (green line) of (A), Bureau of Meteorology precipitation (Jones et al., 2009; Australian Bureau of Meteorology, 2014), (B), upper level soil moisture, and (C), lower level soil moisture from the Australian Water Availability Project (AWAP; Raupach et al., 2009) as fractions, all spatially averaged over the Lake Eyre Catchment for the period January 1900 to February 2014 and (D), the level of water at one site (viz. Belt Bay) in Lake Eyre. Triangles identify synoptic systems associated with heavy rain days. Lake Eyre lake levels compiled by the Lake Eyre Yacht Club from Landsat imagery (since 1979) and data from Bye et al. (1978) calibrated with direct observations.

frequency filter. However, the lower soil moisture 12-month running mean is in close agreement with the monthly data and appears to match the lake level (D) quite well. This suggests that the behavior of this sub-surface layer acts as a low frequency filter on the precipitation.

The Lake Frome record displays some similar characteristics to the much larger Lake Eyre catchment but the lake level peaks are considerably lower than those recorded for Lake Eyre. Figure 6 shows the precipitation, lower and upper soil moisture and lake levels for Lake Frome with the synoptic systems associated with heavy rain events marked by colored triangles in panels A and C. As in the Lake Eyre case, the lower level soil moisture 12-month running mean $(\mathrm{C})$ matches the lake level data relatively well and appears to provide a measure of the low frequency response of Lake Frome and its catchment to precipitation.

\section{LAKE FILLING AND ENSO}

The strong tendency for the heavy rain events considered here to occur in the austral summer and autumn suggests that the intensity and persistence of the Australasian summer monsoon is a key factor in lake-filling episodes. In turn, the summer monsoon is closely influenced by the phase and intensity of the ENSO cycle. In order to investigate the association of ENSO with heavy rainfall in the lake catchments, the daily heavy rain events have been
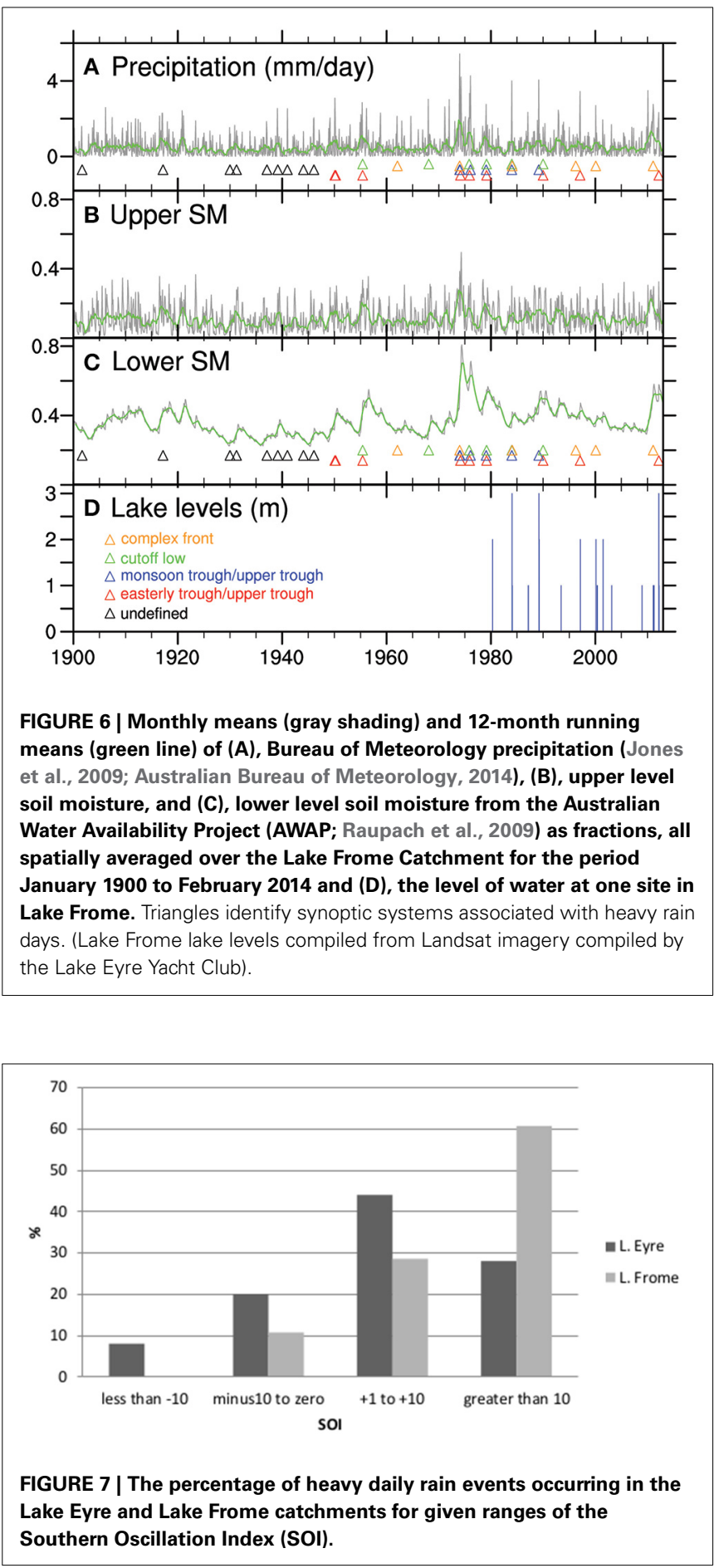

partitioned according to the mean value of the SOI for the month in which the event occurred.

Figure 7 indicates that about $90 \%$ of the heavy daily rain events in the Lake Frome catchment (25 events) occurred when the SOI was in its positive phase and over $70 \%$ in the case of Lake Eyre. Furthermore, at Lake Frome, the SOI exceeded +10 on $61 \%$ of occasions (17 events) and in the Lake Eyre analysis the SOI was greater than +10 in $28 \%$ of the cases (7). The Australian Bureau 
of Meteorology applies a threshold figure to the SOI of +8 over a "sustained" period in order to define La Niña episodes.

\section{DISCUSSION AND CONCLUDING REMARKS}

A climatological analysis has been completed of the synoptic systems associated with heavy precipitation events in the Lake Eyre and Lake Frome catchments of central, southern Australia since 1950. The analysis reveals that tropical influences during the austral summer and autumn dominate significant daily precipitation occurrences in the Lake Eyre catchment. On the MSLP surface, these occurrences were characterized by convergence in a monsoon trough over northern Australia or, at the very least, a well-defined trough of low pressure in the easterly flow. However, the striking feature of the majority of these events was the presence of an accompanying trough or cutoff low in the middle troposphere $(500 \mathrm{hPa})$ and a negative anomaly in $1000-500 \mathrm{hPa}$ thickness relative to the long-term climatology. Further south, at Lake Frome, approximately one half of the events also had these characteristics but over $20 \%$ of events affecting that catchment were associated with Southern Ocean cold fronts which interacted with a prefrontal trough extending from the sub-tropics (complex fronts). Individual cutoff lows accounted for between 10 and $15 \%$ of heavy rain events in each catchment. Heavy rain events associated with surface troughs without upper air support were identified on only about $10 \%$ of occasions at Lake Eyre and $7 \%$ of occasions at Lake Frome. These findings indicate that synoptic analyses confined to mean sea level are inadequate for providing a complete understanding of these heavy rain events.

Although the climatology was based on heavy daily precipitation events, it is evident that one heavy fall of rain over a 24-h period is not capable of producing a lake-filling episode. These rare occurrences are associated with a persistence of rain events, usually in association with a well-developed Australasian summer monsoon which in turn, is closely influenced by the phase and intensity of the ENSO cycle. At least $80 \%$ of the heavy rain events examined in this study across both catchments occurred when the Southern Oscillation as measured by the SOI was in its positive phase. Strikingly, in the Lake Frome case, the SOI exceeded +10 on $60 \%$ of occasions, suggesting that the background atmospheric state in the Pacific Ocean and Australasia was tilted toward La Niña. At Lake Frome, all the events occurred outside winter, suggesting tropical interaction was a key component of the synoptic processes. Overall, it was a key finding of this study that the Lake Frome catchment derives significant rainfall from both tropical and subtropical synoptic types, and from connections between the higher latitudes and the tropics.

Hydrological modeling of the two catchments using high quality rainfall data as an input reveals that a 12-month running mean of the moisture content in the sub-surface soil layer coincides quite well with the historical lake levels. The degree of saturation of this sub-surface layer appears to act as a low pass filter on the catchment precipitation in a similar way to the finding of Ummenhofer et al. (2011). This property could possibly be employed in future attempts to predict lake levels following periods of heavy rain.

\section{ACKNOWLEDGMENTS}

Michael J. Pook, James S. Risbey and Peter R. Briggs acknowledge the contribution of the Commonwealth Scientific and Industrial Research Organisation Oceans and Atmosphere Flagship to this work. Caroline C. Ummenhofer was supported through the Penzance and John P. Chase Memorial Endowed Funds at Woods Hole Oceanographic Institution and Timothy J. Cohen received funding from an ARC Discovery project (DP0667182). We would like to thank Bob Backway (Lake Eyre Yacht Club) for providing the compiled Lake Eyre and Lake Frome dataset.

\section{REFERENCES}

Allan, R. J. (1985). The Australasian Summer Monsoon, Teleconnections, and Flooding in the Lake Eyre Basin. South Australian Geographical Papers No. 2. Royal Geographical Society of Australasia, Adelaide, SA.

Allan, R., Lindesay, J., and Parker, D. (1996). El Niño Southern Oscillation and Climatic Variability. Melbourne, VIC: CSIRO Publishing.

Australian Bureau of Meteorology. (2014). Australian Water Availability Project Online Gridded Meteorological Surfaces. Available online at: http://www.bom. gov.au/jsp/awap/ (Accessed June 2009-March 2014).

Bonython, C. W., and Fraser, A. S. (eds.). (1989). The great filling of Lake Eyre in 1974. R. Geogr. Soc. 119.

Bye, J. A. T., Dillon, P. J., Vandenberg, J. C., and Will, G. D. (1978). Bathymetry of Lake Eyre. Trans. R. Soc. S. Aust. 102, 85-89.

Cathcart, M. (2009). The Water Dreamers (The Remarkable History of our Dry Continent). Melbourne: Text Publishing.

Cohen, T. J., Nanson, G. C., Jansen, J. D., Gliganic, L. A., May, J.-H., Larsen, J., et al. (2012b). A pluvial episode identified in arid Australia during the Medieval Climatic Anomaly. Q. Sci. Rev. 56, 167-171. doi: 10.1016/j.quascirev.2012.09.021

Cohen, T. J., Nanson, G. C., Jansen, J. D., Jones, B. G., Jacobs, Z., Larsen, J. R., et al. (2012a). Late Quaternary mega-lakes fed by the northern and southern river systems of central Australia: varying moisture sources and increased continental aridity. Palaeogeogr. Palaeoclimatol. Palaeoecol. 356, 357, 89-108. doi: 10.1016/j.palaeo.2011.06.023

Cohen, T. J., Nanson, G. C., Jansen, J. D., Jones, B. G., Jacobs, Z., Treble, P., et al. (2011). Continental aridification and the vanishing of Australia's megalakes. Geology 39, 67-170. doi: 10.1130/G31518.1

Gliganic, L. A., Cohen, T. J., May, J.-H., Jansen, J. D., Nanson, G. C., Dosseto, A., et al. (2014). Late Holocene climatic variability indicated by three natural archives in arid Australia. Holocene 24, 104-117. doi: $10.1177 / 0959683613515732$

Guymer, L. B. (1978). Operational Application of Satellite Imagery to Synoptic Analysis in the Southern Hemisphere. Technical Report, 29, Bureau of Meteorology, Melbourne, VIC.

Jones, D. A., Wang, W., and Fawcett, R. (2009). High-quality spatial climate datasets for Australia. Aust. Meteorol. Ocean. J. 58, 233-248.

Kalnay, E., Kanamitsu, M., Kistler, R., Collins, W., Deaven, D., Gandin, L., et al. (1996). The NCEP/NCAR 40-year reanalysis project. Bull. Am. Meteorol. Soc. $77,437-471$.

Kingsford, R. T., and Porter, J. L. (1995). Waterbirds of Lake Eyre, Australia. Biol. Conserv. 65, 141-151. doi: 10.1016/0006-3207(93)90443-5

Kistler, R., Kalnay, E., Collins, W., Saha, S., White, G., Woollen, J., et al. (2001). The NCEP/NCAR 50-year reanalysis project. Bull. Amer. Meteor. Soc. 82, 247-267. doi: 10.1175/1520-0477(2001)082<0247:TNNYRM > 2.3.CO;2

Knighton, A. D., and Nanson, G. C. (1994). Flow transmission along an arid zone anastomosing river, Cooper Creek, Australia. Hydrol. Process 8, 137-154. doi: 10.1002/hyp.3360080205

Kotwicki, V. (1986). Floods of Lake Eyre. Adelaide, SA: South Australia Engineering and Water Supply Department.

Kotwicki, V., and Isdale, P. (1991). Hydrology of Lake Eyre, Australia El Niño link. Palaeogeogr. Palaeoclimatol. Palaeoecol. 84, 87-98. doi: 10.1016/00310182(91)90037-R

Lake Eyre Committee. (1955). Lake Eyre, South Australia:the great flooding of 1949-1950. R. Geogr. Soc. 75. 
Magee, J. W., Miller, G. H., Spooner, N. A., and Questiaux, D. (2004). Continuous 150 k.y. monsoon record from Lake Eyre, Australia: Insolationforcing implications and unexpected Holocene failure. Geology 32, 885-888. doi: 10.1130/G20672.1

McBride, J. L. (1998). "Indonesia, Papua New Guinea and tropical Australia: the Southern Hemisphere monsoon," in Meteorology of the Southern Hemisphere, Vol. 27, Meteorological Monograph, eds D. J. Karoly and D. G. Vincent (Boston, MA: American Meteorology Society), 89-99.

Pook, M. J., McIntosh, P. C., and Meyers, G. A. (2006). The synoptic decomposition of cool-season rainfall in the Southeastern Australian Cropping region. J. Appl. Meteorol. Clim. 45, 1156-1170. doi: 10.1175/ JAM2394.1

Pook, M. J., Risbey, J. S., and McIntosh, P. C. (2012). The synoptic climatology of cool-season rainfall in the Central Wheatbelt of Western Australia. Mon. Weather Rev. 140, 28-43. doi: 10.1175/MWR-D-11-00048.1

Pook, M. J., Risbey, J. S., and McIntosh, P. C. (2014). A comparative synoptic climatology of cool-season rainfall in major grain-growing regions of southern Australia. Theor. Appl. Climatol. 117, 521-533. doi: 10.1007/s00704-013$1021-y$

Poulter, B., Frank, D., Ciais, P., Myneni, R. B., Andela, N., Bi, J., et al. (2014). Contribution of semi-arid ecosystems to interannual variability of the global carbon cycle. Nature 509, 600-603. doi: 10.1038/nature 13376

Raupach, M. R., Briggs, P. R., Haverd, V., King, E. A., Paget, M., and Trudinger, C. M. (2009). Australian Water Availability Project (AWAP): CSIRO Marine and Atmospheric Research Component: Final Report for Phase 3. Canberra, ACT: CAWCR Technical Report No. 013.

Raupach, M. R., Briggs, P. R., Haverd, V., King, E. A., Paget, M., and Trudinger, C. M. (2014). CSIRO Australian Water Availability Project Model Data Release 26j. CSIRO Marine and Atmospheric Research, Canberra, Australia. Available online at: http://www.csiro.au/awap (Accessed April 10, 2014).

Risbey, J. M., Pook, P., McIntosh, M., Wheeler, M. C., and Hendon, H. (2009). On the remote drivers of rainfall variability in Australia. Mon. Wea. Rev. 137, 3233-3253. doi: 10.1175/2009MWR2861.1
Simmonds, I., and Richter, T. (2000). Synoptic comparison of cold events in summer and winter in Melbourne and Perth. Theor. Appl. Climatol. 67, 19-32. doi: 10.1007/s007040070013

Sturman, A., and Tapper, N. (1996). The Weather and Climate of Australia and New Zealand. Melbourne, VIC: Oxford University Press.

Ummenhofer, C. C., Sen Gupta, A., Briggs, P. R., England, M. H., McIntosh, P. C., Meyers, G. A., et al. (2011). Indian and Pacific Ocean influences on Southeast Australian drought and soil moisture. J. Clim. 24, 1313-1336. doi: 10.1175/2010JCLI3475.1

Webb, S. (2010). Palaeotrophic reconstruction and climatic forcing of mega-Lake Eyre in late Quaternary Central Australia: a review. Boreas 39, 312-324. doi: 10.1111/j.1502-3885.2009.00120.x

Wright, W. J. (1989). A synoptic climatological classification of winter precipitation in Victoria. Aust. Meteorol. Mag. 37, 217-229.

Wright, W. J. (1997). Tropical-extratropical cloudbands and Australian rainfall: 1. Climatology. Int. J. Climatol. 17, 807-829.

Conflict of Interest Statement: The authors declare that the research was conducted in the absence of any commercial or financial relationships that could be construed as a potential conflict of interest.

Received: 04 September 2014; accepted: 11 November 2014; published online: 28 November 2014.

Citation: Pook MJ, Risbey JS, Ummenhofer CC, Briggs PR and Cohen TJ (2014) A synoptic climatology of heavy rain events in the Lake Eyre and Lake Frome catchments. Front. Environ. Sci. 2:54. doi: 10.3389/fenvs.2014.00054

This article was submitted to Atmospheric Science, a section of the journal Frontiers in Environmental Science.

Copyright (c) 2014 Pook, Risbey, Ummenhofer, Briggs and Cohen. This is an openaccess article distributed under the terms of the Creative Commons Attribution License (CC BY). The use, distribution or reproduction in other forums is permitted, provided the original author(s) or licensor are credited and that the original publication in this journal is cited, in accordance with accepted academic practice. No use, distribution or reproduction is permitted which does not comply with these terms. 